\title{
Foliar Nutrition: A Novel Technology to Increase Growth and Yield in Baby Corn (Zea mays L.)
}

\author{
G.K. Prajwal Kumar", B.S. Lalitha, K.N. Kalyana Murthy and V. Bhavya \\ Department of Agronomy, College of Agriculture, University of Agricultural Sciences, \\ Bengaluru-560065, Karnataka, India \\ *Corresponding author
}

\section{A B S T R A C T}

\section{Keywords}

Foliar nutrition, Baby corn, Growth, yield, UAS Bengaluru

Article Info

Accepted:

10 March 2018

Available Online:

10 April 2018
A field experiment was conducted at Zonal Agricultural Research Station, University of Agricultural Sciences, Gandhi Krishi Vignana Kendra, Bengaluru during kharif 2016 to study the effect of foliar application of macro and micro nutrients on growth and yield attributes of baby corn (Zea mays L.). The experiment was laid out in a Randomised Complete Block Design with nine treatments replicated thrice. Application of $75 \% \mathrm{RDF}+$ 1.5\% 19:19:19 spray + 0.2\% $\mathrm{ZnSO}_{4}+0.1 \% \mathrm{FeSO}_{4}$ recorded significantly higher baby corn and green fodder yield (244.05 $\mathrm{q} \mathrm{ha}^{-1}$ and $85.16 \mathrm{t} \mathrm{ha}^{-1}$, respectively) and was on par with application of $75 \% \mathrm{RDF}+1.5 \% 19: 19: 19$ spray $+0.5 \% \mathrm{ZnSO}_{4}+0.1 \% \mathrm{FeSO}_{4}(212.37 \mathrm{q}$ $\mathrm{ha}^{-1}$ and $76.82 \mathrm{t} \mathrm{ha}^{-1}$, respectively). This was attributed by enhanced growth parameters viz., plant height $(144.91 \mathrm{~cm})$, total dry matter $\left(152.28 \mathrm{~g} \mathrm{plant}^{-1}\right)$, Absolute growth rate $\left(1.79 \mathrm{~g} \mathrm{day}^{-1}\right)$, Crop growth rate $\left(1.77 \mathrm{~g}^{-2}\right.$ day $\left.^{-1}\right)$, Net assimilation rate $\left(5.56 \mathrm{~g} \mathrm{dm}^{-2} \mathrm{day}^{-1}\right)$, Leaf area index (6.84), Leaf area duration (78.53 days) and yield attributes like number of cobs plant $^{-1}(3.67)$, length of babies $(10.90 \mathrm{~cm})$, girth of babies $(4.07 \mathrm{~cm})$ and weight of babies $\left(23.87 \mathrm{~g} \mathrm{cob}^{-1}\right)$.

\section{Introduction}

Baby corn is an unfertilized, young and immature cob harvested for vegetable purpose during silk emergence and the left out green material serves as quality green fodder for cattle. Chinese are using young cobs as vegetable for generations and it has spread to other Asian counties due to change in tradition and culture and also invasion of westernized lifestyle. The food habit in India has drastically changed over decades which has waved path for popularization of baby corn consumption and even production. At present, baby corn has shown immense potential for cooking and canning industry. Thailand, Japan and Europe are the major importers of canned cob and it has good future too. Baby corn has short growth period, thus the crop can fit very well in the cropping system. The adaptation range of this crop is wide and does not need intensive cultivation as compared to other crops.

The availability of macro and micronutrients added to the soil are affected by soil environmental factors leading to various losses. Foliar application is a particular 
technique to supply macro and micro-nutrients which avoids wastage or loss of nutrients which enhances nutrient use efficiency and reduces the cost of cultivation. Again foliar application of nutrients will be an added advantage in rapid absorption. The foliar nutrition can prevent soil nutrient overloading and lower the risk of environmental threats. During the foliar nutrition, nutrient efficiency can reach up to 85 per cent whereas application of fertilizers through soil has only 30-60 per cent of efficiency depending on nutrient type.

Foliar feeding was stimulated by Tukey and Wittwer during 1950's at Michigan State University, using radioactive isotopes of known plant nutrients which were absorbed by plant foliage and translocated throughout the plant (Dorneanu et al., 2011). There are mainly two advantages of foliar application of fertilizers over soil application viz., about more than 90 per cent fertilizers are utilized by the plant when applied in foliar form and about 95 per cent of the foliar fed nutrients are translocated. After supplying nutrients through foliar spray are found in the smallest root within 60 minutes, if conditions are optimum and foliar fertilizer use efficiency in sandy loam soils is upto 20 times more effective when compared to soil applied fertilizers. (Manasa and Devaranavadagi, 2015) Keeping these things in view studies were conducted to study the effect of foliar application of macro and micro nutrients on growth and yield attributes of baby corn (Zea mays L.)

\section{Materials and Methods}

The field experiment was carried out to study the response of baby corn (Zea mays L.) for foliar application of macro and micro nutrients on growth, yield and quality during kharif season of 2016. The material used and the techniques adopted during the course of this investigation are described in this chapter. The experiment was conducted at Zonal Agricultural Research Station (ZARS), Gandhi Krishi Vignana Kendra, University of Agricultural Sciences, Bengaluru which is situated at $13^{\circ} 05^{\prime}$ North latitude and $77^{\circ} 34^{\prime}$ East longitude and at an altitude of $924 \mathrm{~m}$ above mean sea level which comes under eastern dry zone (ACZ-V) of Karnataka. The soils of the experimental site are red sandy clay loam. Composite soil samples were taken at random from upper $30 \mathrm{~cm}$ layer and were analyzed for physico-chemical properties. The soil reaction was neutral (6.56), medium in available nitrogen (428.37 kg ha ${ }^{-1}$ ), available phosphorus (45.56 kg $\mathrm{P}_{2} \mathrm{O}_{5} \mathrm{ha}^{-1}$ ), available potassium $\left(243.93 \mathrm{~kg} \mathrm{~K}_{2} \mathrm{O} \mathrm{ha}{ }^{-1}\right)$, low in zinc (0.48 ppm) and iron (1.80 ppm).

\section{Treatment details}

$$
\begin{aligned}
& \mathrm{T}_{1}: 50 \% \mathrm{RDF}+1.0 \% 19: 19: 19 \text { spray }+0.2 \% \\
& \mathrm{ZnSO}_{4}+0.1 \% \mathrm{FeSO}_{4}
\end{aligned}
$$

$\mathrm{T}_{2}: 50 \% \mathrm{RDF}+1.0 \% 19: 19: 19$ spray $+0.5 \%$ $\mathrm{ZnSO}_{4}+0.1 \% \mathrm{FeSO}_{4}$

$\mathrm{T}_{3}: 50 \% \mathrm{RDF}+1.5 \% 19: 19: 19$ spray $+0.2 \%$ $\mathrm{ZnSO}_{4}+0.1 \% \mathrm{FeSO}_{4}$
$\mathrm{T}_{4}: 50 \% \mathrm{RDF}+1.5 \% 19: 19: 19$ spray $+0.5 \%$ $\mathrm{ZnSO}_{4}+0.1 \% \mathrm{FeSO}_{4}$

$\mathrm{T}_{5}: 75 \% \mathrm{RDF}+1.0 \% 19: 19: 19$ spray $+0.2 \%$ $\mathrm{ZnSO}_{4}+0.1 \% \mathrm{FeSO}_{4}$

$\mathrm{T}_{6}: 75 \% \mathrm{RDF}+1.0 \% 19: 19: 19$ spray $+0.5 \%$ $\mathrm{ZnSO}_{4}+0.1 \% \mathrm{FeSO}_{4}$

$\mathrm{T}_{7}: 75 \% \mathrm{RDF}+1.5 \% 19: 19: 19$ spray $+0.2 \%$ $\mathrm{ZnSO}_{4}+0.1 \% \mathrm{FeSO}_{4}$

$\mathrm{T}_{8}: 75 \% \mathrm{RDF}+1.5 \% 19: 19: 19$ spray $+0.5 \%$ $\mathrm{ZnSO}_{4}+0.1 \% \mathrm{FeSO}_{4}$

$\mathrm{T}_{9}$ : UAS (B) package (150:75:40 kg N: $\mathrm{P}_{2} \mathrm{O}_{5}$ : $\mathrm{K}_{2} \mathrm{O}$ ha $^{-1}$ ) 
Note: Nitrogen in RDF has been applied in two splits, one at the time of sowing (50\%) and other at $30 \mathrm{DAS}(50 \%)$, respectively.

19:19:19 foliar spray was given at 20 and 40 DAS, $\mathrm{ZnSO}_{4}$ and $\mathrm{FeSO}_{4}$ spray was given at 30 DAS. Quantity of spray solution used was 500 litres $\mathrm{ha}^{-1}$. For all plots FYM was applied @ $10 \mathrm{t} \mathrm{ha}^{-1}$.

\section{Observations on growth parameters}

The various growth parameters such as plant height, number of leaves plant ${ }^{-1}$, leaf area plant $^{-1}$, absolute growth rate, crop growth rate, net assimilation rate, leaf area index, leaf area duration, dry matter production were recorded at different growth stages of baby corn crop.

\section{Plant height}

The plant height $(\mathrm{cm})$ was recorded from five randomly selected and labelled plants.

Plant height was taken from the base of the plant to tip of the newly opened leaf. The mean plant height was worked out and expressed in centimeter.

\section{Number of leaves}

Total number of fully opened green leaves of five plants was counted and their average was taken as the number of leaves plant ${ }^{-1}$.

\section{Leaf area}

The green leaves from the selected plants were fed to the leaf area meter and expressed as $\mathrm{cm}^{2}$ plant $^{-1}$ (Model Li-300 from Licor Co Nebraska)

\section{Absolute growth rate}

Absolute growth rate (AGR) refers to the total growth of a plant per unit time. For various growth periods it was worked out from the below mentioned formula of Watson (1952) and expressed in $\mathrm{g} \mathrm{day}^{-1}$.

$\mathrm{AGR}=\mathrm{W}_{2}-\mathrm{W}_{1} / \mathrm{t}_{2}-\mathrm{t}_{1}$

Where,

$\mathrm{W}_{2}=$ Dry matter production plant ${ }^{-1}(\mathrm{~g})$ at $\mathrm{t}_{2}$ $\mathrm{W}_{1}=$ Dry matter production plant ${ }^{-1}(\mathrm{~g})$ at $\mathrm{t}_{1}$ $\mathrm{t}_{1}$ and $\mathrm{t}_{2}=$ time intervals

\section{Crop growth rate}

Crop growth rate (CGR) for various growth periods was worked out from the below given formula of Watson (1952) and expressed in $\mathrm{g}^{-2}$ day $^{-1}$.

\section{$\mathrm{CGR}=\mathrm{W} 2-\mathrm{W} 1 / \mathrm{t} 2-\mathrm{t} 1 \times \mathrm{P}$}

Where,

$\mathrm{W}_{2}=$ Dry matter production plant ${ }^{-1}(\mathrm{~g})$ at $\mathrm{t}_{2}$

$\mathrm{W}_{1}=$ Dry matter production plant ${ }^{-1}(\mathrm{~g})$ at $\mathrm{t}_{1}$

$\mathrm{t}_{1}$ and $\mathrm{t}_{2}=$ time intervals

$\mathrm{P}=$ land area $\left(\mathrm{cm}^{2}\right)$

\section{Net assimilation rate}

Net assimilation rate (NAR) is defined as the rate of increase of dry weight per unit of leaf area. NAR for various growth periods was worked out from the below given formula of Gregory (1926) and expressed in $\mathrm{g} \mathrm{dm}^{-2} \mathrm{day}^{-1}$.

\section{NAR $=$ W2-W1/t2-t1 x LogeL2-LogeL1/L2-}

\section{L1}

Where,

$\mathrm{W}_{2}=$ Dry matter production plant ${ }^{-1}(\mathrm{~g})$ at $\mathrm{t}_{2}$ $\mathrm{W}_{1}=$ Dry matter production plant ${ }^{-1}(\mathrm{~g})$ at $\mathrm{t}_{1}$ $\mathrm{t}_{1}$ and $\mathrm{t}_{2}=$ time intervals

$\mathrm{L}_{1}=\mathrm{LAI}$ at time $\mathrm{t}_{1}$

$\mathrm{L}_{2}=\mathrm{LAI}$ at time $\mathrm{t}_{2}$ 


\section{Leaf area index}

Leaf area index (LAI) is defined as an assimilatory surface per unit area of land (Sestak et al., 1971).

Leaf area index was worked out at 15, 30, 45 days after sowing and at harvest by dividing the leaf area plant ${ }^{-1}$ by land area occupied by the plant.

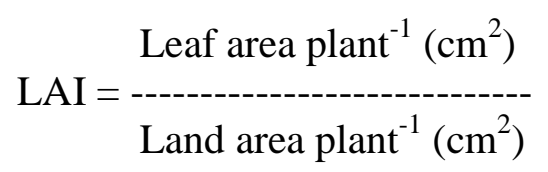

\section{Leaf area duration}

Leaf area duration (LAD) is the integration of leaf area index over a growth period (Watson, 1952). For various growth periods LAD was worked out from the formula of Powar et al., (1967) and expressed in days.

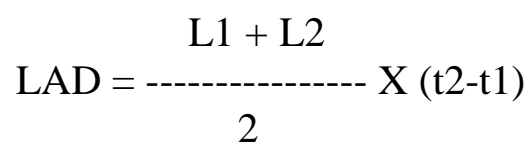

Where,

$\mathrm{L}_{1}=\mathrm{LAI}$ at time $\mathrm{t}_{1}$

$\mathrm{L}_{2}=\mathrm{LAI}$ at time $\mathrm{t}_{2}$

$t_{2}-t_{1}=$ Time interval between crop growth period in days

\section{Dry matter production and accumulation}

Total dry matter production in leaf and stem was recorded at 15, 30, 45 DAS and at harvest from five randomly selected plants in each plot.

Samples were dried at $65^{\circ} \mathrm{C}$ to attain constant weight and average dry weight was calculated and expressed in grams per plant.

\section{Observation on yield parameters}

\section{Length of husked and de husked baby corn}

Length of baby corn was measured by using linear scale from base to tip of the baby and expressed in centimeter.

\section{Girth of husked and de husked baby corn}

Circumference of the husked and dehusked baby corn was measured using thread and expressed in centimeter.

\section{Weight of husked and de husked baby corn}

Freshly harvested husked baby corn mean weight was recorded and expressed in grams. In the similar way fresh weight of dehusked baby corn was also recorded. De husked baby corn were sun dried and later dried in hot air oven at $65{ }^{\circ} \mathrm{C}$ till to get constant weight. The mean dry weight of a baby corn was taken and expressed in grams.

\section{Husked and dehusked baby corn yield}

Husked and dehusked baby corn yield from net plot was converted into quintals per hectare.

\section{Green fodder yield}

Green fodder yield from net plot was converted into tonnes per hectare.

\section{Statistical analysis and interpretation of data}

The experimental data collected on growth, yield and quality components of plant were subjected to Fisher's method of "Analysis of Variance" (ANOVA) as outlined by Panse and Sukhatme (1967). Wherever, F- test was significant, for comparison among the treatment means, an appropriate value of 
critical difference (C.D.) was worked out. If Ftest found non-significant, against C.D. values NS (Non-Significant) was indicated. All the data were analyzed and the results were presented and discussed at a probability level of five per cent. Correlation matrix was worked out between growth, yield and quality parameters (Gomez and Gomez, 1984).

\section{Results and Discussion}

\section{Plant height}

Application of $75 \% \mathrm{RDF}+1.5 \%$ 19:19:19 spray $+0.2 \% \mathrm{ZnSO}_{4}+0.1 \% \mathrm{FeSO}_{4}$ has recorded significantly higher plant height (Table 1) at harvest $(144.91 \mathrm{~cm})$ and was on par with application of $75 \% \mathrm{RDF}+1.5 \%$ 19:19:19 spray $+0.5 \% \mathrm{ZnSO}_{4}+0.1 \% \mathrm{FeSO}_{4}$ $(134.31 \mathrm{~cm})$. Significantly lower plant height was recorded at harvest with application of $50 \% \mathrm{RDF}+1.0 \% 19: 19: 19$ spray $+0.2 \%$ $\mathrm{ZnSO}_{4}+0.1 \% \mathrm{FeSO}_{4}(116.07 \mathrm{~cm})$. Significant variation in the plant height is due to in time availability of the needed nutrients to the plant at the important growth stages and application of zinc has led to production of IAA resulting in increased plant height (Manasa and Devaranavadagi, 2015). Nitrogen and zinc also helped in more leaf area as a consequence more assimilates were produced and increased the plant height (Jasim Iqbal et al., 2016). These results are in conformity with Asghar $e t$ al., (2011), Mahmoud (2001) and Parasuraman (2008). Generally, P has positive significant interaction with $\mathrm{N}$ absorption and plant growth (Sumner et al., 1986).

\section{Number of leaves}

Application of $75 \% \mathrm{RDF}+1.5 \%$ 19:19:19 spray $+0.2 \% \mathrm{ZnSO}_{4}+0.1 \% \mathrm{FeSO}_{4}$ recorded significantly higher number of leaves plant $^{-1}$ (Table 1) at harvest (11.47) which was on par with application of 75\% RDF + 1.5\% 19:19:19 spray $+0.5 \% \mathrm{ZnSO}_{4}+0.1 \% \mathrm{FeSO}_{4}(11.20)$.
Significantly lower number of leaves plant ${ }^{-1}$ were recorded at harvest with application of $50 \% \mathrm{RDF}+1.0 \% 19: 19: 19$ spray $+0.2 \%$ $\mathrm{ZnSO}_{4}+0.1 \% \mathrm{FeSO}_{4}$ (10.13). The synergistic effect of both nitrogen and zinc helps in rapid growth and development of plants as they help in photosynthesis and various plant biochemical processes which responds towards growth (Jasim Iqbal et al., 2016).

\section{Leaf area}

Application of $75 \%$ RDF $+1.5 \%$ 19:19:19 spray $+0.2 \% \mathrm{ZnSO}_{4}+0.1 \% \mathrm{FeSO}_{4}$ recorded significantly higher leaf area (Table 1) at harvest $\left(9229.37 \mathrm{~cm}^{2}\right.$ plant $\left.^{-1}\right)$ which was on par with application of $75 \% \mathrm{RDF}+1.5 \%$ 19:19:19 spray + 0.5\% $\mathrm{ZnSO}_{4}+0.1 \% \mathrm{FeSO}_{4}$ $\left(8627.11 \mathrm{~cm}^{2}\right.$ plant $\left.^{-1}\right)$. Significantly lower leaf area was recorded at harvest with application of 50\% RDF + 1.0\% 19:19:19 spray + 0.2\% $\mathrm{ZnSO}_{4}+0.1 \% \mathrm{FeSO}_{4}\left(7223.37 \mathrm{~cm}^{2}\right.$ plant $\left.^{-1}\right)$. The higher leaf area was due to the increased plant height resulted into more number of nodes per plant leading to more number of leaves per plant. The results on leaf area index across the crop growth stages differed significantly. The formation of optimum photosynthetic stage for longer period was through timely supply of nutrients by foliar nutrition. On the other side, the improved photosynthetic capacity was highly influenced by the foliar fertilization of major nutrients viz., nitrogen, phosphorus and potassium including the micronutrients (Watson, 1952).

\section{Absolute growth rate}

Among the different treatments, (Table 2) application of $75 \% \mathrm{RDF}+1.5 \% 19: 19: 19$ spray $+0.2 \% \mathrm{ZnSO}_{4}+0.1 \% \mathrm{FeSO}_{4}$ has recorded significantly higher absolute growth rate $\left(1.79 \mathrm{~g} \mathrm{day}^{-1}\right.$ at 45 days-harvest $)$. However, application of $75 \% \mathrm{RDF}+1.5 \%$ 19:19:19 spray $+0.5 \% \mathrm{ZnSO}_{4}+0.1 \% \mathrm{FeSO}_{4}$ recorded on par results with the above 
treatment (1.73 $\mathrm{g} \mathrm{day}^{-1}$ at 45 days-harvest). Significantly lower absolute growth rate was recorded with application of $50 \% \mathrm{RDF}+1.0 \%$ 19:19:19 spray $+0.2 \% \mathrm{ZnSO}_{4}+0.1 \% \mathrm{FeSO}_{4}$ (1.06 $\mathrm{g} \mathrm{day}^{-1}$ at 45 days-harvest).

\section{Crop growth rate}

Application of $75 \% \mathrm{RDF}+1.5 \%$ 19:19:19 spray $+0.2 \% \mathrm{ZnSO}_{4}+0.1 \% \mathrm{FeSO}_{4}$ has recorded significantly higher crop growth rate (Table 2) i.e., $1.77 \mathrm{~g} \mathrm{~m}^{-2}$ day $^{-1}$ at 45 daysharvest which was on par with application of $75 \% \mathrm{RDF}+1.5 \%$ 19:19:19 spray $+0.5 \%$ $\mathrm{ZnSO}_{4}+0.1 \% \mathrm{FeSO}_{4}\left(1.55 \mathrm{~g} \mathrm{~m}^{-2}\right.$ day $^{-1}$ at 45 days-harvest). Significantly lower crop growth rate was recorded with application of $50 \%$ $\mathrm{RDF}+1.0 \% 19: 19: 19$ spray $+0.2 \% \mathrm{ZnSO}_{4}+$ $0.1 \% \mathrm{FeSO}_{4}\left(0.86 \mathrm{~g} \mathrm{~m}^{-2}\right.$ day $^{-1}$ at 45 daysharvest).

\section{Net assimilation rate}

Significantly higher net assimilation rate (Table 2) was recorded with application of $75 \% \mathrm{RDF}+1.5 \% 19: 19: 19$ spray $+0.2 \%$ $\mathrm{ZnSO}_{4}+0.1 \% \mathrm{FeSO}_{4}\left(5.56 \mathrm{~g}^{-1} \mathrm{dm}^{-2}\right.$ leaf area ${ }^{-1}$ day $^{-1}$ at 45 days-harvest) which was on par with application of 75\% RDF + 1.5\% 19:19:19 spray $+0.5 \% \mathrm{ZnSO}_{4}+0.1 \% \mathrm{FeSO}_{4}\left(5.41 \mathrm{~g}^{-1}\right.$ $\mathrm{dm}^{-2}$ leaf area $^{-1} \mathrm{day}^{-1}$ at 45 days-harvest). Significantly lower net assimilation rate was recorded with application of $50 \% \mathrm{RDF}+1.0 \%$ 19:19:19 spray $+0.2 \% \mathrm{ZnSO}_{4}+0.1 \% \mathrm{FeSO}_{4}$ (2.69 $\mathrm{g}^{-1} \mathrm{dm}^{-2}$ leaf area $^{-1} \mathrm{day}^{-1}$ at 45 daysharvest).

\section{Leaf area index}

At harvest (Table 2), application of $75 \%$ RDF $+1.5 \% 19: 19: 19$ spray $+0.2 \% \mathrm{ZnSO}_{4}+0.1 \%$ $\mathrm{FeSO}_{4}$ has recorded significantly higher leaf area index (6.84) and was on par with application of $75 \% \mathrm{RDF}+1.5 \%$ 19:19:19 spray $+0.5 \% \mathrm{ZnSO}_{4}+0.1 \% \mathrm{FeSO}_{4}$ (6.39). Significantly lower leaf area index was recorded with application of $50 \% \mathrm{RDF}+1.0 \%$ 19:19:19 spray $+0.2 \% \mathrm{ZnSO}_{4}+0.1 \% \mathrm{FeSO}_{4}$ (5.35).

\section{Leaf area duration}

At 45 DAS - at harvest (Table 2), application of $75 \% \mathrm{RDF}+1.5 \% 19: 19: 19$ spray $+0.2 \%$ $\mathrm{ZnSO}_{4}+0.1 \% \quad \mathrm{FeSO}_{4}$ has recorded significantly higher leaf area duration (78.53 days). Significantly lower leaf area duration was recorded with application of 50\% RDF + $1.0 \% 19: 19: 19$ spray $+0.2 \% \mathrm{ZnSO}_{4}+0.1 \%$ $\mathrm{FeSO}_{4}$ (60.75 days).

The higher growth indices were resultant of higher growth parameters viz., plant height, number of leaves, leaf area and dry matter accumulation in various parts. Production of photosynthates and their translocation to sink depends upon availability of mineral nutrients like potassium, whose availability has increased the zinc uptake also. Most of the photosynthetic pathways are dependent on enzymes and co-enzymes, which are synthesized by mineral nutrients such as nitrogen, phosphorus and potassium activated by zinc. Nitrogen is an integral part of chlorophyll and a component of protoplasm protein, nucleic acid and plays a vital role in vegetative and reproductive phase of crop growth. The differences in the growth parameters could be attributed to rapid cell division and elongation through the effect of nitrogen. The results are in conformity with Roopashree (2013).

\section{Dry matter production and accumulation}

\section{Dry matter accumulation in leaves}

Application of $75 \%$ RDF $+1.5 \%$ 19:19:19 spray $+0.2 \% \mathrm{ZnSO}_{4}+0.1 \% \mathrm{FeSO}_{4}$ has recorded significantly higher dry matter accumulation in leaves (Table 3) at harvest (67.11 $\mathrm{g} \mathrm{plant}^{-1}$ ) and which was on par with 
application of $75 \% \mathrm{RDF}+1.5 \% \quad 19: 19: 19$ spray $+0.5 \% \mathrm{ZnSO}_{4}+0.1 \% \mathrm{FeSO}_{4}(65.50 \mathrm{~g}$ plant $\left.^{-1}\right)$. Significantly lower dry matter accumulation in leaves were recorded at harvest with application of 50\% RDF $+1.0 \%$ 19:19:19 spray + 0.2\% $\mathrm{ZnSO}_{4}+0.1 \% \mathrm{FeSO}_{4}$ (53.58 g plant $\left.^{-1}\right)$.

\section{Dry matter accumulation in stem}

Application of $75 \% \mathrm{RDF}+1.5 \% 19: 19: 19$ spray $+0.2 \% \mathrm{ZnSO}_{4}+0.1 \% \mathrm{FeSO}_{4}$ has recorded significantly higher dry matter accumulation in stem (Table 3) at harvest $\left(85.17 \mathrm{~g} \mathrm{plant}^{-1}\right)$ and which was on par with application of $75 \% \mathrm{RDF}+1.5 \%$ 19:19:19 spray $+0.5 \% \mathrm{ZnSO}_{4}+0.1 \% \mathrm{FeSO}_{4}(83.13 \mathrm{~g}$ plant $^{-1}$ ).

Significantly lower dry matter accumulation in stem were recorded at harvest with application of $50 \% \mathrm{RDF}+1.0 \% 19: 19: 19$ spray $+0.2 \%$ $\mathrm{ZnSO}_{4}+0.1 \% \mathrm{FeSO}_{4}\left(68.01 \mathrm{~g} \mathrm{plant}^{-1}\right)$.

\section{Total dry matter accumulation}

Application of $75 \%$ RDF $+1.5 \%$ 19:19:19 spray $+0.2 \% \mathrm{ZnSO}_{4}+0.1 \% \mathrm{FeSO}_{4}$ has recorded significantly higher total dry matter accumulation (Table 3) at harvest (152.28 g plant $^{-1}$ ).

Significantly lower total dry matter accumulation was recorded at harvest with application of $50 \% \mathrm{RDF}+1.0 \% 19: 19: 19$ spray $+0.2 \% \mathrm{ZnSO}_{4}+0.1 \% \mathrm{FeSO}_{4}(121.59 \mathrm{~g}$ plant $\left.^{-1}\right)$.

Increased dry matter production is due to balanced amount of macro and micro nutrients through foliar fertilization which resulted in better crop growth and photosynthetic activity which led to better supply of photosynthates ultimately resulted in higher dry matter production per plant. Potassium in the foliar fertilizers had helped in osmotic regulation and increased metabolic activity of plants through synergistic effect with zinc. Additional nitrogen from the foliar fertilizer besides split application influenced the vegetative growth in plant and reduced the fertilizer loss resulted in higher dry matter production per plant. The results are in conformity with the findings of Parasuraman (2008), Thavaprakaash et al., (2006) and Abdou El- Nour (2002).

The foliar spray given at different crop growth stages might have closely synchronised to the nutrient requirements leading to better absorption, translocation and assimilation of nitrogen and potassium by plants leading to significant increase in dry matter yield. The results are also in line with the findings of Afifi et al., (2011).

\section{Length of husked and de husked baby corn}

Significantly higher length of cob (Table 4) with husk was recorded application of $75 \%$ $\mathrm{RDF}+1.5 \%$ 19:19:19 spray + 0.2\% $\mathrm{ZnSO}_{4}+$ $0.1 \% \mathrm{FeSO}_{4}(25.72 \mathrm{~cm})$ which was on par with application of $75 \% \mathrm{RDF}+1.5 \%$ 19:19:19 spray $+0.5 \% \mathrm{ZnSO}_{4}+0.1 \% \mathrm{FeSO}_{4}(24.67$ $\mathrm{cm})$. Significantly lower length of cob with husk was recorded with application of $50 \%$ $\mathrm{RDF}+1.0 \%$ 19:19:19 spray + 0.2\% $\mathrm{ZnSO}_{4}+$ $0.1 \% \mathrm{FeSO}_{4}(21.68 \mathrm{~cm})$.

Among the different treatments, application of $75 \%$ RDF $+1.5 \%$ 19:19:19 spray $+0.2 \%$ $\mathrm{ZnSO}_{4}+0.1 \% \mathrm{FeSO}_{4}(10.90 \mathrm{~cm})$ recorded significantly higher length of cob without husk (Table 4). However, application of 75\% RDF $+1.5 \%$ 19:19:19 spray $+0.5 \% \mathrm{ZnSO}_{4}+0.1 \%$ $\mathrm{FeSO}_{4}(10.47 \mathrm{~cm})$ recorded on par results with the above treatment.

Significantly lower length of cob with husk was recorded with application of $50 \% \mathrm{RDF}+$ $1.0 \% 19: 19: 19$ spray $+0.2 \% \mathrm{ZnSO}_{4}+0.1 \%$ $\mathrm{FeSO}_{4}(9.27 \mathrm{~cm})$. 
Table.1 Plant height, number of leaves and leaf area of baby corn at harvest as influenced by foliar nutrition

\begin{tabular}{|c|c|c|c|}
\hline \begin{tabular}{c} 
Treatments \\
\hline $\mathrm{T}_{1}$
\end{tabular} & Plant height $(\mathrm{cm})$ & $\begin{array}{c}\text { Number of } \\
\text { Leaves plant }\end{array}$ & $\begin{array}{c}\text { Leaf area } \\
\left.\text { (cm }^{2} \text { plant }^{-1}\right)\end{array}$ \\
\hline $\mathrm{T}_{2}$ & 116.07 & 10.13 & 7223.37 \\
\hline $\mathrm{T}_{3}$ & 119.85 & 10.20 & 7345.39 \\
\hline $\mathrm{T}_{4}$ & 121.81 & 10.33 & 7503.91 \\
\hline $\mathrm{T}_{5}$ & 124.37 & 10.40 & 7603.06 \\
\hline $\mathrm{T}_{6}$ & 127.75 & 10.67 & 7786.66 \\
\hline $\mathrm{T}_{7}$ & 133.02 & 10.73 & 7991.37 \\
\hline $\mathrm{T}_{8}$ & 144.91 & 11.47 & 9229.37 \\
\hline $\mathrm{T}_{9}$ & 134.31 & 11.20 & 8627.11 \\
\hline S.Em. \pm & 133.97 & 10.80 & 8145.83 \\
\hline C.D. $(\boldsymbol{p}=\mathbf{0 . 0 5})$ & 3.60 & 0.22 & 332.78 \\
\hline C.V. $(\%)$ & 10.80 & 0.65 & 998.36 \\
\hline
\end{tabular}

Table.2 Absolute growth rate, crop growth rate, net assimilation rate, leaf area index and leaf area duration of baby corn at harvest as influenced by foliar nutrition

\begin{tabular}{|c|c|c|c|c|c|}
\hline Treatments & $\begin{array}{l}\text { Absolute } \\
\text { growth rate } \\
\left(\text { g day }^{-1}\right)\end{array}$ & $\begin{array}{l}\text { Crop } \\
\text { growth } \\
\text { rate }\left(\mathrm{g} \mathrm{m}^{-2}\right. \\
\left.\text { day }^{-1}\right)\end{array}$ & $\begin{array}{c}\text { Net } \\
\text { assimilation } \\
\text { rate }\left(\mathrm{g}^{-1} \mathbf{~ d m}^{-}\right. \\
{ }^{2}{\text { leaf } \text { area }^{-1}}_{\left.\text {day }^{-1}\right)}\end{array}$ & $\begin{array}{l}\text { Leaf area } \\
\text { index }\end{array}$ & $\begin{array}{c}\text { Leaf area } \\
\text { duration } \\
\text { (days) }\end{array}$ \\
\hline $\mathbf{T}_{1}$ & 1.06 & 0.86 & 2.69 & 5.35 & 60.75 \\
\hline $\mathbf{T}_{2}$ & 1.10 & 0.93 & 2.81 & 5.44 & 61.58 \\
\hline $\mathbf{T}_{3}$ & 1.20 & 1.08 & 3.21 & 5.56 & 63.90 \\
\hline $\mathbf{T}_{4}$ & 1.39 & 1.25 & 4.15 & 5.63 & 64.50 \\
\hline $\mathbf{T}_{\mathbf{5}}$ & 1.47 & 1.32 & 4.65 & 5.77 & 66.53 \\
\hline $\mathrm{T}_{6}$ & 1.52 & 1.37 & 4.58 & 5.92 & 67.43 \\
\hline $\mathrm{T}_{7}$ & 1.79 & 1.77 & 5.56 & 6.84 & 78.53 \\
\hline $\mathrm{T}_{8}$ & 1.73 & 1.55 & 5.41 & 6.39 & 72.53 \\
\hline $\mathrm{T}_{9}$ & 1.57 & 1.41 & 4.68 & 6.03 & 68.48 \\
\hline S.Em. \pm & 0.19 & 0.17 & 0.23 & 0.26 & 1.86 \\
\hline C.D. $(p=0.05)$ & 0.57 & 0.51 & 0.70 & 0.80 & 5.59 \\
\hline C.V. $(\%)$ & 7.72 & 8.81 & 9.48 & 8.97 & 10.69 \\
\hline
\end{tabular}


Table.3 Dry matter in leaves, dry matter in stem and total dry matter of baby corn at harvest as influenced by foliar nutrition

\begin{tabular}{|c|c|c|c|}
\hline Treatments & $\begin{array}{l}\text { Dry matter in leaves } \\
\left(\mathrm{g} \mathrm{plant}^{-1}\right)\end{array}$ & $\begin{array}{l}\text { Dry matter in stem } \\
\left(\text { g plant }^{-1}\right)\end{array}$ & $\begin{array}{c}\text { Total dry matter (g } \\
\left.\text { plant }^{-1}\right)\end{array}$ \\
\hline $\mathbf{T}_{1}$ & 53.58 & 68.01 & 121.59 \\
\hline $\mathbf{T}_{2}$ & 53.88 & 68.38 & 122.26 \\
\hline $\mathbf{T}_{\mathbf{3}}$ & 54.83 & 69.59 & 124.42 \\
\hline $\mathbf{T}_{4}$ & 56.64 & 71.88 & 128.52 \\
\hline $\mathbf{T}_{5}$ & 56.96 & 72.28 & 129.24 \\
\hline $\mathrm{T}_{6}$ & 62.17 & 78.90 & 141.07 \\
\hline $\mathbf{T}_{7}$ & 67.11 & 85.17 & 152.28 \\
\hline $\mathbf{T}_{8}$ & 65.50 & 83.13 & 148.63 \\
\hline $\mathbf{T}_{9}$ & 62.95 & 79.88 & 142.83 \\
\hline S.Em. \pm & 1.36 & 1.74 & 7.20 \\
\hline C.D. $(p=0.05)$ & 4.08 & 5.20 & 21.59 \\
\hline C.V. $(\%)$ & 9.28 & 9.27 & 8.12 \\
\hline
\end{tabular}

Table.4 Length of cob, girth of cob, fresh weight of cob, dry weight of cob of baby corn at harvest as influenced by foliar nutrition

\begin{tabular}{|c|c|c|c|c|c|c|c|c|}
\hline \multirow[t]{2}{*}{ Treatments } & \multicolumn{2}{|c|}{$\begin{array}{l}\text { Length of cob } \\
\text { (cm) }\end{array}$} & \multicolumn{2}{|c|}{$\begin{array}{l}\text { Girth of cob } \\
(\mathrm{cm})\end{array}$} & \multicolumn{2}{|c|}{$\begin{array}{l}\text { Fresh weight of } \\
\text { cob }\left(\mathrm{g} \mathrm{cob}^{-1}\right)\end{array}$} & \multicolumn{2}{|c|}{$\begin{array}{c}\text { Dry weight of } \\
\text { cob }\left(\mathrm{g} \mathrm{cob}^{-1}\right)\end{array}$} \\
\hline & $\begin{array}{l}\text { with } \\
\text { husk }\end{array}$ & $\begin{array}{c}\text { without } \\
\text { husk }\end{array}$ & $\begin{array}{l}\text { with } \\
\text { husk }\end{array}$ & $\begin{array}{c}\text { without } \\
\text { husk }\end{array}$ & $\begin{array}{l}\text { with } \\
\text { husk }\end{array}$ & $\begin{array}{l}\text { without } \\
\text { husk }\end{array}$ & $\begin{array}{l}\text { with } \\
\text { husk }\end{array}$ & $\begin{array}{c}\text { without } \\
\text { husk }\end{array}$ \\
\hline $\mathbf{T}_{1}$ & 21.68 & 9.27 & 69.75 & 16.10 & 69.75 & 16.10 & 13.04 & 5.03 \\
\hline $\mathbf{T}_{2}$ & 22.63 & 9.30 & 74.78 & 16.73 & 74.78 & 16.73 & 13.88 & 5.23 \\
\hline $\mathbf{T}_{\mathbf{3}}$ & 23.17 & 9.37 & 76.58 & 17.40 & 76.58 & 17.40 & 13.73 & 5.44 \\
\hline $\mathbf{T}_{4}$ & 23.58 & 9.47 & 80.77 & 17.73 & 80.77 & 17.73 & 16.25 & 5.54 \\
\hline $\mathbf{T}_{5}$ & 23.92 & 9.83 & 83.67 & 17.80 & 83.67 & 17.80 & 16.84 & 5.56 \\
\hline $\mathrm{T}_{6}$ & 24.30 & 9.97 & 85.95 & 20.17 & 85.95 & 20.17 & 18.88 & 6.30 \\
\hline $\mathbf{T}_{7}$ & 25.72 & 10.90 & 93.87 & 23.87 & 93.87 & 23.87 & 20.61 & 7.46 \\
\hline $\mathbf{T}_{8}$ & 24.67 & 10.47 & 91.02 & 21.40 & 91.02 & 21.40 & 19.54 & 6.69 \\
\hline $\mathbf{T}_{9}$ & 24.58 & 10.37 & 87.08 & 21.23 & 87.08 & 21.23 & 18.95 & 6.64 \\
\hline S.Em. \pm & 0.37 & 0.17 & 1.29 & 0.84 & 1.29 & 0.84 & 0.48 & 0.27 \\
\hline C.D. $(p=0.05)$ & 1.11 & 0.51 & 3.85 & 2.52 & 3.85 & 2.52 & 1.46 & 0.80 \\
\hline C.V. $(\%)$ & 6.54 & 5.83 & 6.54 & 5.83 & 8.84 & 8.25 & 8.68 & 8.11 \\
\hline
\end{tabular}


Table.5 Dry matter in leaves, dry matter in stem and total dry matter of baby corn at harvest as influenced by foliar nutrition

\begin{tabular}{|c|c|c|c|}
\hline \multirow[t]{2}{*}{ Treatments } & \multicolumn{2}{|c|}{ Baby corn yield $\left(q \mathrm{ha}^{-1}\right)$} & \multirow{2}{*}{$\begin{array}{l}\text { Green fodder } \\
\text { yield }\left(\mathrm{t} \mathbf{h a}^{-1}\right)\end{array}$} \\
\hline & with husk & without husk & \\
\hline$\overline{T_{1}}$ & 124.64 & 26.83 & 124.64 \\
\hline$\overline{T_{2}}$ & 127.64 & 27.89 & 127.64 \\
\hline$\overline{T_{3}}$ & 150.76 & 32.48 & 150.76 \\
\hline $\mathbf{T}_{4}$ & 156.18 & 33.23 & 156.18 \\
\hline $\mathbf{T}_{5}$ & 171.90 & 40.33 & 171.90 \\
\hline$T_{6}$ & 174.17 & 42.80 & 174.17 \\
\hline $\mathbf{T}_{7}$ & 244.05 & 60.30 & 244.05 \\
\hline $\mathrm{T}_{8}$ & 212.37 & 49.54 & 212.37 \\
\hline$T_{9}$ & 189.28 & 48.08 & 189.28 \\
\hline S.Em. \pm & 15.95 & 3.68 & 15.95 \\
\hline C.D. $(p=0.05)$ & 47.83 & 11.04 & 47.83 \\
\hline C.V. $(\%)$ & 9.48 & 8.88 & 9.48 \\
\hline
\end{tabular}

\section{Girth of husked and de husked baby corn}

Significantly higher girth of cob with husk (Table 4) was recorded application of $75 \%$ $\mathrm{RDF}+1.5 \% 19: 19: 19$ spray $+0.2 \% \mathrm{ZnSO}_{4}+$ $0.1 \% \mathrm{FeSO}_{4}(8.00 \mathrm{~cm})$ which was on par with application of $75 \% \mathrm{RDF}+1.5 \%$ 19:19:19 spray $+0.5 \% \mathrm{ZnSO}_{4}+0.1 \% \mathrm{FeSO}_{4}(7.76 \mathrm{~cm})$. Significantly lower girth of cob with husk was recorded with application of $50 \% \mathrm{RDF}+$ $1.0 \% 19: 19: 19$ spray $+0.2 \% \mathrm{ZnSO}_{4}+0.1 \%$ $\mathrm{FeSO}_{4}(6.96 \mathrm{~cm})$.

Among the different treatments, application of $75 \% \mathrm{RDF}+1.5 \% 19: 19: 19$ spray $+0.2 \%$ $\mathrm{ZnSO}_{4}+0.1 \% \mathrm{FeSO}_{4}(4.07 \mathrm{~cm})$ recorded significantly higher girth of cob without husk (Table 4) which was on par with application of $75 \% \mathrm{RDF}+1.5 \% 19: 19: 19$ spray $+0.5 \%$ $\mathrm{ZnSO}_{4}+0.1 \% \mathrm{FeSO}_{4}(4.00 \mathrm{~cm})$. Significantly lower girth of cob without husk was recorded with application of $50 \% \mathrm{RDF}+1.0 \%$ 19:19:19 spray $+0.2 \% \mathrm{ZnSO}_{4}+0.1 \% \mathrm{FeSO}_{4}$ $(3.38 \mathrm{~cm})$.

The improvement in length and girth of cob was due to additive effect of macro and micro nutrients. The results obtained are in conformity with Roopashree (2013).

\section{Weight of husked and de husked baby corn}

Application of $75 \% \mathrm{RDF}+1.5 \%$ 19:19:19 spray $+0.2 \% \mathrm{ZnSO}_{4}+0.1 \% \mathrm{FeSO}_{4}$ recorded (Table 4) significantly higher fresh weight and dry weight of cob with husk (93.87 g $\mathrm{cob}^{-1}$ and $20.61 \mathrm{~g} \mathrm{cob}^{-1}$, respectively) and which was on par with application of $75 \%$ $\mathrm{RDF}+1.5 \%$ 19:19:19 spray + 0.5\% $\mathrm{ZnSO}_{4}+$ $0.1 \% \mathrm{FeSO}_{4}\left(91.02 \mathrm{~g} \mathrm{cob}^{-1}\right.$ and $19.54 \mathrm{~g} \mathrm{cob}^{-1}$, respectively). Significantly lower fresh weight and dry weight of cob with husk was recorded with application of $50 \% \mathrm{RDF}+1.0 \%$ 19:19:19 spray $+0.2 \% \mathrm{ZnSO}_{4}+0.1 \% \mathrm{FeSO}_{4}$ $\left(69.75 \mathrm{~g} \mathrm{cob}^{-1}\right.$ and $16.10 \mathrm{~g} \mathrm{cob}^{-1}$, respectively).

Among the different treatments, application of $75 \% \mathrm{RDF}+1.5 \% 19: 19: 19$ spray $+0.2 \%$ $\mathrm{ZnSO}_{4}+0.1 \% \quad \mathrm{FeSO}_{4}$ (Table 4) recorded significantly higher fresh weight and dry weight of cob without husk (23.87 $\mathrm{g} \mathrm{cob}^{-1}$ and $7.46 \mathrm{~g} \mathrm{cob}^{-1}$, respectively) which was on par with application of $75 \% \mathrm{RDF}+1.5 \%$ 
19:19:19 spray $+0.5 \% \mathrm{ZnSO}_{4}+0.1 \% \mathrm{FeSO}_{4}$ (21.40 $\mathrm{g} \mathrm{cob}^{-1}$ and $6.69 \mathrm{~g} \mathrm{cob}^{-1}$, respectively). Significantly lower fresh weight of cob without husk was recorded with application of $50 \% \mathrm{RDF}+1.0 \% 19: 19: 19$ spray $+0.2 \%$ $\mathrm{ZnSO}_{4}+0.1 \% \mathrm{FeSO}_{4}\left(16.10 \mathrm{~g} \mathrm{cob}^{-1}\right.$ and $5.03 \mathrm{~g}$ $\mathrm{cob}^{-1}$, respectively).

The fresh and dry weight of cobs varied due to genetic potential of hybrid and differential application of macro and micro nutrients resulted in higher cob length and cob girth resulted in higher fresh weight of cob. The results are also in line with the findings of Afifi et al., (2011).

The higher cob weight of baby corn crop was due to the positive influence exerted by potassium on the weight of cob, since it involved in the transportation of carbohydrates to the sink that is babies. In addition to that, presence of phosphorus in the foliar fertilizers enhanced better absorption of nitrogen by the plant. The presence of zinc in the foliar fertilizer which is necessary for protein synthesis ensuring the quality, uniform maturity and better absorption of nitrogen by the plant leading to increased photosynthesis and increased weight of cob. The results are in conformation with work done by Manja Naik (2012) and Manasa and Devaranavadagi (2015).

\section{Husked and dehusked baby corn yield}

Application of $75 \%$ RDF + 1.5\% 19:19:19 spray $+0.2 \% \mathrm{ZnSO}_{4}+0.1 \% \mathrm{FeSO}_{4}$ (Table 5) recorded significantly higher baby corn yield with husk and without husk (244.05 q ha ${ }^{-1}$ and $60.30 \mathrm{q} \mathrm{ha}^{-1}$, respectively) which was on par with application of $75 \% \mathrm{RDF}+1.5 \%$ 19:19:19 spray + 0.5\% $\mathrm{ZnSO}_{4}+0.1 \% \mathrm{FeSO}_{4}$ (212.37 $\mathrm{q} \mathrm{ha}^{-1}$ and $49.54 \mathrm{q} \mathrm{ha}^{-1}$, respectively). Significantly lower baby corn yield with husk and without husk was recorded with application of $50 \% \mathrm{RDF}+1.0 \% 19: 19: 19$ spray $+0.2 \% \mathrm{ZnSO}_{4}+0.1 \% \mathrm{FeSO}_{4}(124.64 \mathrm{q}$ $\mathrm{ha}^{-1}$ and $26.83 \mathrm{q} \mathrm{ha}^{-1}$, respectively). Significantly higher cob yield was mainly attributed to the significantly higher cob length, cob girth, number of cobs and fresh weight of cob. Substantial improvement in yield and yield attributing parameters were observed in baby corn treated with foliar spray of $\mathrm{ZnSO}_{4}$ at 9 leaf stage as per Tariq et al., (2014). These results are also in line with the work of Saeed and Mohammad (2012), Asghar et al., (2011), Potarzyki and Grzebisz (2009), Parasuraman (2008), Dorneanu et al., (2011), Mahmoud (2001) and Afifi et al., (2011).

\section{Green fodder yield}

Significantly higher green fodder yield was recorded with application of $75 \% \mathrm{RDF}+$ $1.5 \%$ 19:19:19 spray $+0.2 \% \mathrm{ZnSO}_{4}+0.1 \%$ $\mathrm{FeSO}_{4}\left(85.16 \mathrm{t} \mathrm{ha}^{-1}\right)$ which was on par with application of $75 \% \mathrm{RDF}+1.5 \% \quad 19: 19: 19$ spray $+0.5 \% \mathrm{ZnSO}_{4}+0.1 \% \mathrm{FeSO}_{4}(76.82 \mathrm{t}$ $\mathrm{ha}^{-1}$ ). Significantly lower green fodder yield was recorded with application of 50\% RDF + $1.0 \% 19: 19: 19$ spray $+0.2 \% \mathrm{ZnSO}_{4}+0.1 \%$ $\mathrm{FeSO}_{4}\left(57.18 \mathrm{tha}^{-1}\right)$.

Higher growth parameters viz., plant height, number of leaves and leaf area index led to higher total dry matter production per plant which attributed to higher green fodder yield over other treatments. The results are in line with Asghar et al., (2011) and Parasuraman (2008).

Improved yield and growth attributes might be interpreted as the manifestation of higher nutrient uptake by the plants. Increase in dry matter production per unit area is a first step in achieving higher yield. Dry matter production at different growth stages of any crop is an important pre requisite for higher yields as it signifies photosynthetic ability of the crop (Asghar et al., 2011). 


\section{References}

Abdou El-Nour, E. A. A., 2002, Can supplemented potassium foliar feeding reduce the recommended soil potassium? Pakistan J. Biol. Sci., 5 (3): 259-262.

Afifi, M. H. M., Khalifa, R. K. M. And Camilia, Y., 2011, Urea foliar application as a partial substitution of soil-applied nitrogen fertilization for some maize cultivars grown in newly cultivated soil. Australian J. Basic Appl. Sci., 5 (7): 826-832.

Asghar, A., Azhar, G. M., Mummad, W., Ayub, M., Asif, I. And Atta, U. M., 2011, Influence of integrated nutrients on growth, yield and quality of maize. American J. Plant Sci., 1 (2): 63-69.

Dorneanu, A., Emilia, D. And Prodan, T., 2011, Ecological fertilization of agricultural crops using foliar fertilizers. Central Research Station for Plant Growing on Sandy soils, Dabuleni-Dolji, 2 (1): 56-64.

Gomez, K. A. And Gomez, A. K., 1984, Statistical procedures for Agricultural Research, $2^{\text {nd }}$ Ed: John Wiley and Sons, New York, pp: 105-114.

Gregory, F.G., 1926, The effect of climatic conditions on growth of barley. Ann. Bot., 46: 1-26.

Jasim Iqbal, Rayyan Khan, Abdul Wahid, Kamil Sardar, Nangial Khan, Murad Ali, Mujahid Hussain, Waqar Ali, Mukhtiar Ali And Rafiq Ahmad, 2016, Effect of nitrogen and zinc on maize (Zea mays L.) yield components and plant concentration. Adv. Envi. Bio., 10 (10) : 203-208.

Mahmoud, M. S., 2001, Effect of tracenutrient foliar fertilizer on nutrient balance, growth, yield and yield components of two cereal crops. Pakistan J. Biol. Sci., 4 (7): 770-774.
Manasa, L. P. And Devaranavadagi, S. B., 2015, Effect of foliar application of micronutrients on growth, yield and nutrient uptake of maize. Karnataka $J$. Agric. Sci., 28 (4): 474-476.

Manja Naik, U., 2012, Performance of maize to fertilizer levels and foliar nutrition under northern transition zone of Karnataka. M. Sc. (Agri) Thesis, Univ. Agric. Sci., Dharwad, Karnataka.

Panse, V. G. And Sukhatme, P. V., 1967, Statistical methods for agricultural workers. ICAR, Publ., New Delhi, pp: 359.

Parasuraman, P., 2008, Studies on integrated nutrient requirement of hybrid maize (Zea mays L.) under irrigated conditions. Madras Agric. J., 92 (1): 8994.

Potarzycki, J. And Grzebisz, W., 2009, Effect of zinc foliar application on grain yield of maize and its yielding components. American-Eurasian J. Agri. Envi. sci., 12 (7): 954-959.

Powar, J. F., Willid, W. O., Grunes, D. I. And Reichman, C. A., 1967, Effect of soil temperature, phosphorus and plant age on growth analysis of Barley. Agron. J., 59: 231-234.

Roopashree, D. H., 2013, Effect of organic manures, mulching and potassium levels on growth, yield and quality of baby corn (Zea mays L.). Ph. D. (Thesis), Univ. Agric. Sci., Bengaluru.

Saeed, G. And Mohammad Yousefi, 2012, Yield and yield component of Maize. American-Eurasian J. Agric. Env. Sci., 12 (9): 1246-1251.

Sestak, A. L., Catasky, T. And Jarvis, P. G., 1971, Plant Photosynthetic Production Manual of Methods, Edited by: Dr. Junk, W. N. V., Publication, The Haghu, pp: 343-345.

Sumner, M. E. And Farina, M. P. W., 1986, Phosphorus interactions with other 
nutrients and lime in field cropping systems. Adv. Soil Sci., 5: 201-236.

Tariq, A., Anjum, S. A., Randhawa, M. A., Ullah, E., Naeem, M., Qamar, R., Ashraf, U. And Nadeem, M., 2014, Influence of Zinc Nutrition on growth and yield behaviour of maize (Zea mays L.) hybrids. American J. Pl. Sci., 5: 2646-2654.
Thavaprakaash, N., Velayudham, K. and Panneerselvam, S., 2006, Foliar nutrition of baby corn. Archives Agron. Soil Sci., 52 (4): 419 - 425.

Watson, D. J., 1952, The physiological basis for variation in yield. Adv. Agron., 4: 101-145.

\section{How to cite this article:}

Prajwal Kumar, G.K., B.S. Lalitha, K.N. Kalyana Murthy and Bhavya, V. 2018. Foliar Nutrition: A Novel Technology to Increase Growth and Yield in Baby Corn (Zea mays L.). Int.J.Curr.Microbiol.App.Sci. 7(04): 1136-1148. doi: https://doi.org/10.20546/ijcmas.2018.704.125 